УАK 342.7

ББК 67.400 .3

DOI 10.22394/1682-2358-2020-6-10-27

D.S. Velieva, Doctor of Sciences (Law), Professor, Head of the Constitutional and International Law Department, Povolzbsky Institute of Management named after P.A. Stolypin, Branch of the Russian Presidential Academy of National Economy and Public Administration

M.V. Presnyakov, Doctor of Sciences (Law), Professor of the Service and Labor Law Department, Povolzhsky Institute of Management named after P.A. Stolypin, Branch of the Russian Presidential Academy of National Economy and Public Administration

\section{EXECUTION OF JUDGMENTS OF THE EUROPEAN COURT OF HUMAN RIGHTS: NATIONAL DEMOCRATIC PROCEDURES VS. LEGAL CERTAINTY}

The problem of execution of decisions of intergovernmental human rights bodies within the national legal systems is considered. It is noted that this problem has no legal solution in principle. The authors believe that the consensus is to "reformat" the existing mechanism of verification of the European Convention interpretations constitutionality by the European Court from the way of non-execution of ECHR judgments to the way of searching possibilities of complex and comprehensive solutions.

Key words and word-combinations. European Court, Constitutional Court, human rights, legal certainty, national democratic procedures, amendments to the Constitution.
А.С. Велиеъа, доктор гридических наук, профессор, заведуюиий кафедрой конституиионного и международного права Поволжского инстиmута управления имени П.А. Стольтина - филиала Российской академии народного хозяйства и государственной службь при Президенте РФ (email: ya.wds05@yandex.ru)

М.В. Пресняков, доктор юридических наук, профессор кафедрь служебного и трудового права Поволжского института управления имени П.А. Стольтина - филиала Российской академии народного хозяйства и государственной службь при Президенте РФ (email: presnykov1972@yandex.ru)

\section{ИСПОАНЕНИЕ РЕШЕНИЙ ЕСПЧ: НАЦИОНААЬНЫЕ АЕМОКРАТИЧЕСКИЕ ПРОЦЕАУРЫ VS ПРАВОВАЯ ОПРЕАЕ $\Lambda$ ЕННОСТЬ ${ }^{*}$}

Аннотация. Рассматривается проблема исполнения решений межгосударственных органов по правам человека в рамках национальных правовых систем. Отмечается, что данная проблема не имеет принципиального юридического решения. Авторы полагают, что консенсус заключается в «переформатировании» существующего механизма проверки конституционности толкований Европейской конвенции Европейским судом из способа неисполнения постановлений ЕСПЧ в поиск возможностей комплексного и всестороннего решения.

Ключевые слова и словосочетания: Европейский суд, Конституционный Суд РФ, права человека, правовая определенность, национальные демократические процедуры, поправки в Конституцию РФ.

*Публикация подготовлена в рамках поддержанного РФФИ научного проекта № 19-011-00418 А. 
K онституиионная реформа 2020 2. и «суверенизачия» российской прабовой системь. Весной - метом 2020 г. в Конституцию РФ в «рекордные» сроки (Аля сравнения - разработка Конституџии РФ 1993 г. в условиях жесточайшего политического кризиса заняла почти три года) было внесено более двухсот поправок. ОАной из основных претензий к конституционной реформе 2020 г. бымо «переписывание» в тексте Основного Закона действующих положений текущего законодательства. Во-первых, это не имеет никакого практического смысла, поскольку указанные правовые предписания уже существуют в правовой системе России и непосреАственно применяются. Во-вторых, совершенно ни к чему перегружать текст российской Конституции положениями, которые обусловлены «политическим моментом», Аа еще и носят в значительной своей части «запретительный» характер.

ОАнако одно из подобных «нововведений», пожалуй, имело смысл закрепить непосредственно в тексте Основного Закона, несмотря на то, что оно не только предусмотрено действующим законодательством, но и имеет определенную практику применения. Имеется в виду норма, согласно которой решения межгосударственных органов, принятые на основании положений межАународных договоров Российской Федерации в их истолковании, противоречащем Конститущии РФ, не подмежкат исполнению в Российской Федераџии. Речь идет не о «безупречности» или Ааже оправданности Аанного полномочия Конститущионного Суда РФ (это весьма неоднозначный вопрос, к которому еще вернемся), а цишь о том, что механизмы подобного рода должны, по нашему мнению, закрепляться только Конституџией, но не текущим законодательством. Это положение первоначально было вкцючено в Федеральный закон о Конституџионном Суде Российской Федераџии и явилось прямым результатом принятия Европейским судом по правам человека решения по делу «Анчугов и Гцадков (Anchugov and Gladkov) против Российской Федераџии» [1, с. 11, 124-142]. Напомним, что в рамках разрешения данного дела Европейский суд воспроизвел свою "устойчивую позиџию», согласно которой недифференџированное (без учета тяжести

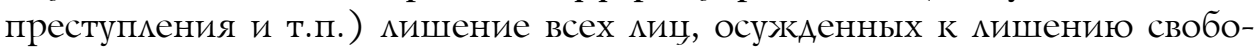
ды, избирательных прав явмяется нарушением Европейской конвенции по правам человека. ОАнако данное ограничение избирательных прав не просто прямо закрепляется в российской Конституции, но и вкцючено в содержание ее второй главы «Права и свободы человека и гражданина», которая, как известно, может изменяться только в результате пересмотра Конституции в целом. Разумеется, подобное решение Европейского суда явилось неприемлемым Аля России, в результате чего и появияся наделавший столько «шума» Федеральный конституционный закон от 14 декабря 2015 г. № 7-ФКЗ. Этот Закон предоставил Конституционному 
Суау РФ полномочие проверять возможность исполнения решений межгосударственных органов по правам человека в том случае, если имеется сомнение о соответствии российской Конституџии того толкования поможений межАународного договора, которое содержится в Аанном решении. Иными словами, речь идет не о противоречии международного договора и Конституџии РФ (такие вопросы должны решаться на стадии его заключения), а о «конфликте толкований» данных положений национальным и межкгосударственным органами.

Указанная проблема, как преАставмяется, с правовой точки зрения носит характер «юридической апории» (греч. а̇лорі́ - «безысходность, безвыходное положение»): с одной стороны, Россия как субъект межАународного права обязалась не только соблюдать Конвенщию о защите прав человека и основных свобод, но и ipso facto признала юрисдикцию Европейского суда. Следовательно, как субъект международного права Российская Федерация обязана выполнить решение Европейского суда, и на межАународном уровне положения наџиональной правовой системы не имеют значения. С Аругой стороны, в силу национального суверенитета, ни один правовой акт не может противоречить Конституции как Основному Закону государства. Если уж на то пошио, то само положение, мегитимизирующее международные договоры как часть национальной правовой системы и придающее им «правоприменительный приоритет» переА положениями национального законодательства, закрепляется нормами Конституции. Аанная проблема, по нашему мнению, неразрешима в юридическом поле и может иметь только политическое решение, что и было сделано еще в 2015 г. путем внесения указанных изменений в Федеральный конституционный закон о Конституционном Суде РФ. Это решение наделало много шума как на международном уровне, так и в России.

Правовая определенность и различние системь толкования содержания основньгх праһ и съобод. Проблема усугубцяется тем, что положения национальных конституций фактически «дублируют» нормы Европейской конвенции по правам человека или наоборот - факт в том, что и решения Европейского суда по правам человека (ЕСПЧ), и практика наџиональных (как правило, конституционных) судов имеют фактически единую нормативную основу. В работе [2] уже отмечалось, что важнейшим условием обеспечения содержательной определенности основных прав и свобод является существование единого и единственного (!) органа, наделенного полномочиями официального толкования соответствующих положений Основного Закона. В противном случае будет очевидно наличие нескольких «фактических конституџий» или офиџиальных интерпретаций конституционного текста по числу органов государственной власти, которые вправе выявлять «действительный смысл» Основного Закона [2, с. 13].

Формально деятельность ЕСПЧ не противоречит принципу «одна конститущия - один конститущионный суА», ведь так проверяется, причем

12 Bulletin of the Volga Region Institute of Administration • 2020. Vol. 20. № 6 
«ad hoc, соблюдение Европейской конвенџии по правам человека. ОАнако в силу того, что текстуально нормы ЕКПЧ и положкения национальных конституций повествуют об одних и тех же правах и свободах, прецеденты ЕСПЧ и правовые позиции конституционных судов представляют собой разАичные интерпретации оАних и тех же норм и оАних и тех же прав. Именно поэтому Закон о Конституџионном Суде РФ предусматривает проџедуру разрешения вопроса о возможности исполнения решения межгосударственного органа по правам человека, принятой на основании положений межаународных договоров Российской Федераџии в их истолковании, противоречащем Конститущии РФ. Иными словами, речь идет о конфликте толкований или интерпретаций прав и свобод национальными и наднациональными органами. В известной степени можно утверждать, что это колмизия «фактической ЕКПЧ» и «фактической Конституџии». При этом Европейский сул по правам человека выступает не только в качестве суда высшей инстанџии, не предусмотренного национальной судебной системой, но и в известном смысле в качестве «надконституционного суда».

Это тем более удивительно, что подобный пересмотр дел представляет собой определенное отступцение от принципа «res judicata», на необходимость соблюдения которого неоднократно обращал внимание сам Европейский суд по правам человека. Аанный принџип ЕСПЧ рассматривает в качестве императива, который вытекает из общего принџипа правовой определенности и предполагает, что окончательное и вступившее в силу решение суда не может пересматриваться, кроме как в силу исключительных обстоятельств. ОАним из таких «исключительных обстоятельств» явмяется выявленное ЕСПЧ нарушение Конвенции о защите прав человека и основных свобод.

Подобное положение дел плохо согласуется с принципом «res judicata» (не говоря уже о независимости судебной власти в рамках национального

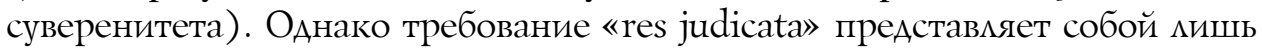
формально-юридическую, «проџедурную» сторону правовой определенности (правовой стабильности), что предполагает минимизацию юридических механизмов вмешательства в правовой статус кичности.

По нашему глубокому убеждению, фокус проблемы правовой опреАеленности цичности на современном этапе правового развития Аавно уже сместился с формально-юридических характеристик (определенности правовых предписаний) к субстанџиальным, предполагающим выяснение вопроса, что именно входит в содержание того или иного права и какие конкретно правомочия из него вытекают. Сами эти права преАставмяют собой «черный ящик», поскольку обладают непозитивным характером: их конкретное содержание не формулируется конституционными или межАународными актами, а выявляется в каждом конкретном скучае. Если рассматривать права человека в субстанциональном смысле, то есть как 
феномен, обладающий собственной реальностью, не зависящий от позитивного закона, то и требование правовой определенности меняет акцент с качества «правовой материи», в рамках которой осуществцяется позитивация того или иного права, на определенность содержания самого права.

В современном правопонимании права и свободы человека носят наАнациональный и надконституционный характер, что, кстати, выражается не только в положениях межаународных документов, но и в конституциях. Так, согласно Конституции РФ, основные права и свободы «неотчуждаемы и принадлежат каждому от рождения» (ст. 17), «явмяются непосредственно действующими» (ст. 18). При этом они не только не предоставляются человеку государством и принадлежат ему изначально (от рождения), но и сами определяют «смысл, содержание и применение законов» (ст. 18). Таким образом, получается, что естественные права человека первичны по отношению к позитивному закону, в том числе и конституции как основному закону.

На первый взгляд данный тезис содержит определенный парадокс, поскольку сами эти права человека закрепляются в конституциях, в частности в главе 2 Конституции РФ. ОАнако не стоит забывать, что позитивное законодательство, в том числе формальная или юридическая конститущия, закрепляет указанные права, но не конституирует их. Учредительный характер конституџии распространяется на систему органов государственной власти, национально-территориальное устройство государства и т.п., но не на права и свободы человека. В подтверждение этого в Конституџии РФ предусматривается, что перечисление в ней основных прав и свобод не Аолжно толковаться как отрицание или умаление Аругих общепризнанных прав и свобод человека и гражданина (ст. 55).

Конституция РФ (как и конституции Аругих государств) содержит многочисленные указания на глобально-консенсуальный характер основных прав и свобод: они гарантируются «согласно общепризнанным принципам и нормам международного права» (ст. 17); признаются не поименованные в Основном Законе, но общепризнанные права и свободы человека (ст. 55); право политического убежища предоставляется в соответствии с общепризнанными нормами международного права (ст. 63) и т.п. Таким образом, наряду с собственно конституџионными правами выделяются «общепризнанные права и свободы», которые при этом также получают конституционное признание и защиту. ОАнако если общепризнанные права и свободы явмяются частью конституционного катацога признаваемых и защищаемых прав, то и претензии конституционного позитивизма в сфере «суверенизации» этих прав и свобоА несостоятельны. Принцип правовой определенности, предполагающий аутентичность содержкания данных прав, предполагает наличие общего консенсуса по данному вопросу. 
МежАу тем данная комлизия толкований положений национальных конституций и международных договоров сама по себе не носит непреодолимого характера. Если вспомнить «дело Маркина» [3], то становится очевидным, что такого «конфмикта толкований» еще неАостаточно Аля отказа от исполнения решения Европейского суда в силу объективной, действительной невозможности его исполнения. Европейский суА по правам человека и Конституционный СуА РФ решительно разошлись в вопросе поиска правового баланса межАу принџипом равенства и задачей обеспечения обороноспособности государства по "делу Маркина», что, однако, совершенно не помешало России исполнить постановление ЕСПЧ, в том чисме применив «меры общего характера», путем внесения изменений в Закон о статусе военнослужащих.

Проблема исполнения решений ЕСПЧ 8 рамках начионального правопорядка (мерь "общего характера»). Аанная проблема не исчерпывается столкновением амбиций национальных конституџионных судов и Европейского суда по правам человека. Представим, что Россия примет решение исполнить, например, решение Европейского суда по делу Анчугова и Гцадкова и внести соответствующее положение в свою Конституцию. Но это не может быть сделано «автоматически», только на основании постановления ЕСПЧ - необходимо использовать демократические процедуры, предусмотренные национальным законодательством. В частности, согласно ст. 135 Конститущии РФ, преАложение об изменении второй главы, а, соответственно, и о пересмотре всего Основного Закона перво-наперво должно быть подАержано тремя пятыми голосов от общего числа чменов Совета Федераџии и депутатов Государственной Аумы РФ. Только после этого собирается Конституџионное Собрание (закона о нем еще нет!), которое мибо подтверждает неизменность Конституции, кибо разрабатывает проект нового Основного Закона, который, в свою очередь, принимается двумя третями голосов уже Конституџионного Собрания, мибо выносится на всенародное голосование. Велика ми вероятность, что поправки, предусматривающие возможность участвовать в выборах миџам, осужденным за совершение преступцения и находящимся в местах кишения свободы, смогут пройти всю эту процеАуру и будут приняты? Это риторический вопрос: преАставляется, что Аанное предложение не сможет набрать даже необходимого количества голосов Аля созыва Конститущионного Собрания!

Вместе с тем реализованная демократическая процедура изменения Конституции РФ не может быть проигнорирована. Именно поэтому рассматриваемая проблема может быть обозначена как «национальные демократические процедуры vs решение Европейского суда по правам чемовека».

Наш «мысленный эксперимент» не является гипотетическим рассуждением, оторванным от реальности, а, как показывает мировая практи- 
ка, представляет собой вполне достоверную модель развития событий. Аело Анчугова и Гцадкова не составляет уникального прецедента «против России» - подобное решение вопроса об избирательных правах миц, осужденных за совершение преступцений, явмяется устойчивой практикой Европейского суда. Например, к аналогичным выводам Суд пришел в деле «Херст против Векикобритании» [4], «Фродль протии Австрии» [5] , «Скоппола против Италии» [6].

Аело Херста показательно тем, что Великобритания предприняла попытку его исполнения и внесла соответствующий законопроект на рассмотрение парламента. ОАнако Палата общин в 2011 г. подавцяющим большинством голосов (234 против 22) отказалась изменить национальное избирательное законодательство с целью исполнения решения Европейского суда $[7$, с. 13$]$.

Не обсуждая в рамках данной работы обоснованность решения ЕСПЧ и весомость доводов властей Великобритании или России, считаем необходимым подчеркнуть существование сложной (практически неразрешимой) институџиональной проблемы, которая связана с практической реализаџией решений Европейского суда в рамках наџионального правопорядка.

Как известно, исполнение решений, вынесенных ЕСПЧ против конкретного государства, предполагает с его стороны принятие мер как частного, так и общего характера [8]. Первые предполагают устранение выявленных нарушений прав человека, предусмотренных Конвенцией; вторые - направлены на предупреждение таких нарушений в будушем, в том числе путем изменения действующего законодательства.

Пречедентная практика Европейского суда и начиональное прабосудие (мерь «частного характера»). Рассматриваемая проблема была ранее обозначена именно в связи с применением мер общего характера, где она проявляется наиболее «рельефно» - принятие закона или отмена уже действующего с необходимостью опосредовано определенными демократическими процедурами, которые предполагают свободное волеизъявление законодательного органа.

ОАнако это не означает, что аналогичная трудность не возникает в связи с принятием мер частного характера (исключая, пожкауй, только выплату «справедиивой компенсации»). Пкенум Верховного Суда РФ в упомянутом постановлении указал, что «суды в пределах своей компетенции должны действовать таким образом, чтобы обеспечить выполнение обязательств государства, вытекающих из участия Российской Федерации в Конвенџии о зашите прав человека и основных свобод». ЗАесь остается не вполне понятным, что имеется в виАу поА выполнением обязательств государства, но «в пределах своей компетенции». Компетенция суда заключается в независимом отправлении правосудия в соответствии с действующим законодательством, вкАючая и положения межАународных Аоговоров, но это

16 Bulletin of the Volga Region Institute of Administration • 2020. Vol. 20. № 6 
не означает, что суды Аолжны «автоматически» исполнять решения ЕСПЧ, поскольку он не является по отношению к ним вышестоящей инстанцией. В противном скучае само понятие «правосудия» в рамках конкретной национацьной системы права теряет смыс.

В данном случае весьма показательна ситуация с исполнением решения Европейского суда по Аелу «Гергюлю против Германии» [9]. На Аанном прецеденте Европейского суАа по правам человека и его сложной «суАьбе» в рамках судебной системы демократической Германии есть смысл остановиться несколько более подробно.

Казим Гергюлю (Kazim Görgülü), будучи гражданином Турции, проживац в Германии. В 1999 г. у него родияся внебрачный ребенок - сын Кристофер. Мать ребенка, с которой он расстался до рождения сына, заявила о желании отдать ребенка на усыновление и в нотариальном порядке Аала свое согласие на усыновление ребенка приемными родителями. С 29 августа 1999 г. мальчик жким у приемных родителей.

Сам Гергюлю узнал о рождении сына только через несколько месяџев и стац предпринимать меры по установцению отцовства. В результате суА первой инстанџии г. Виттенберга своим решением от 20 июня 2000 г. установиц его отцовство и передац ему искцючительное право родительской опеки наА сыном.

ОАнако Высший земельный суд г. Наумбурга по жкалобе приемных роАителей и службы по делам несовершеннолетних отмениц решение сула первой инстанции относительно права опеки, откцониц ходатайство заявителя о передаче ему опеки наА сыном и в интересах ребенка запретил Гергелю свидания и общение с сыном на период до 30 июня 2002 г.

19 января 2001 г. приемные родители ребенка подаци заявление в суд первой инстанции г. Виттенберга о его усыновлении. Гергюлю отказался Аать согласие на усыновление Кристофера, но суд первой инстанции опреАелением от 28 декабря 2001 г. выдал разрешение на усыновление.

В сентябре 2001 г. заявитель обратился в Европейский суА по правам человека (ЕСПЧ) с индивидуацьной жалобой о нарушении ст. 8 Конвенции о защите прав человека и основных свобод, согласно которой кажАый имеет право на уважение его кичной и семейной жкизни. По мнению заявителя, процеАура принудительного усыновления, в ходе которой были проигнорированы права биологического отца, вопиющим образом нарушает данное право. В итоге в постановлении от 26 февраця 2004 г. Европейский суА констатировац нарушение ст. 8 Европейской конвенции и присудиц Гергюлю денежную компенсацию в размере 15 тыс. евро. Вместе с тем, разумеется, Европейский суА не правомочен принимать решения об усыновцении, поэтому Аело вновь оказалось на рассмотрении национацьных судов Германии. Как справедииво отмечается в специальной митературе, «наиболее распространенной мерой индивидуального характера явцяется возобновцение судебного разбирательства, которое предусмот- 
рено немецким процессуальным законодательством и активно реализуется при необходимости на практике» [10, с. 8] .

Суд первой инстанџии вынес решение о передаче ребенка отцу и преАоставиц отцу право встречаться с сыном в течение Авух часов в неАелю Ао вступления в силу этого решения. ОАнако апемляџионный суд в Наумбурге вновь отменил как разрешение на свидания с ребенком, так и само решение суда первой инстанции о передаче сына отщу.

Точку в этой затянувшейся судебной тяжбе пришлось ставить Конституционному и Верховному судам Германии. Мотивы такого упорного нежелания суда г. Наумбурга передать ребенка под опеку биологического отца не вполне ясны: сам Казим Гергюлю объяснял это «ксенофобскими настроениями» судей [11]. Прокуратура впослеАствии преАъявица обвинение судьям в принятии заведомо неправосудного решения, но их вина не была установлена в судебном порядке.

Существенный интерес здесь преАставмяет аргументация, которую привец апемляџионный суд г. Наумбурга в обоснование своего решения. По его мнению, обязательства, которые возникают у Германии в связи с исполнением решений ЕСПЧ как субъекта межАународного права, не означают возникновение у суда как национального органа правосудия обязательства по «автоматическому» принятию соответствующего решения. Указанный Аовод совсем не мишен смысла: если судьи независимы и подчиняются только закону, то принимаемое ими решение не может предопределяться каким-либо иным органом, в том числе и межгосударственным органом по защите прав человека. В противном случае речь булет идти о девацьвации судебной вмасти и частичной передаче функщии правосудия указанному межкосударственному органу.

Федеральный конституционный суА Германии отверг этот Аовод суда г. Наумбурга: «Высший земельный суд неАопустимым с точки зрения конституџионного права образом исходит из того, что решение Европейского суда по правам человека обязывает искцючительно Федеративную Респубцику Германию как субъект международного права, но не немецкие суды. В силу закона все государственные органы Федеративной Респубцики Германии в рамках их компетенџии связаны... нормами Конвенции и вступившими в силу Аля Германии Аополнительными протоколами. Они обязаны учитывать гарантии Конвенщии и судебную практику ЕСПЧ при толковании основных прав и гарантий правового государства» [12].

Иными словами, Конституционный суА констатировац, что обязанность Германии соблюдать принятые Европейским судом решения распространяется и на все органы государственной власти. ОАнако Аанный аргумент, как преАставцяется, явцяется формацьным и в значительной степени казуистическим, поскольку не отвечает на вопрос, каким именно образом суА Аолжен учесть решение ЕСПЧ (а фактически исполнить

18 Bulletin of the Volga Region Institute of Administration • 2020. Vol. 20. № 6 
его!), не теряя своей собственной самостоятельности как органа правосудия. Весьма показательно, что и сам Конституционный суд Германии не считает допустимым простое «механическое» исполнение наџиональными судами постановлений ЕСПЧ. «...Могут возникнуть конституџионные проблемы, если один субъект основных прав в правовом споре с Аругим субъектом добъется бцагоприятного Аля него решения Европейского суда по правам человека против Федеративной Республики Германии и немецкие суды схематично применят это решение к частноправовому отношению, в результате чего «проигравший» в этом деле и, возможно, Ааже не участвовавший в разбирательстве в ЕСПЧ субъект основных прав вообще больше не сможет эффективно защитить свои права как субъект процесса».

На наш взгляА, сложности, обнаружившиеся в связи с «делом Гергюмю», свидетельствуют не о нежелании государств или конкретных органов государственной власти исполнять решения Европейского суда по правам человека, а о гораздо более глубокой проблеме институционального характера. Проблема эта связана с тем, что решение вопросов права в национальных правовых системах опосредовано определенными демократическими процедурами, которые преАполагают известную степень дискреции именно внутригосударственных органов вмасти.

Если речь идет о вопросах, требующих принятия судебного решения, то таким органом выступает наџиональный суА, Аеятельность которого регмаментируется внутригосударственным проџессуальным порядком и преАполагает высокую степень независимости судей, подчинение их искмючительно закону и принятие решения на основе внутреннего убеждения. Реацизаџия итогового решения Европейского суда в рамках наџиональной судебной системы не может сводиться к его «исполнению» в точном значении этого слова. Именно поэтому основным способом выполнения (в рамках мер частного характера) решений ЕСПЧ в Аелах подобного рода выступает пересмотр судебных решений.

Вместе с тем такой пересмотр осуществляется в рамках процеАуры отправления правосудия и не может представцять собой механическое копирование выводов Европейского суда в рамках нового судебного решения. В связи с этим Федеральный конституџионный суд Германии совершенно справедливо отметил, что «как недостаточное исследование решений ЕСПЧ, так и их схематическое «исполнение», которое противоречит вышестояшему праву, могут приводить к нарушению основных прав в сочетании с принџипом правового государства».

Интересно, что саму процеауру пересмотра дел в связи с установлением Европейским судом в деятельности национальных властей нарушения Конвенции («возобновление производства по уголовным делам») ФКС рассматривает как среАство обеспечения «принџипа правовой стабильности», имея в виАу, по всей видимости, не формальную сторону 
юридической определенности, а субстанциональную или правовую определенность мичности как фактическое обладание всем объемом прав и свобод.

Интересно, что на дело Гергюлю ссылаются как сторонники приоритета норм международного права, так и авторы, ратующие за «суверенный» конституционализм. Это связано с тем, что Федеральный конституционный суА Германии, с одной стороны, подтверАиц приверженность соблюАения положений Европейской конвенџии, напомнив, что она является частью правовой системы Германии, а с Аругой, указал, что задачей наџионального правосудия явцяется именно соблюдение указанных положений, а не их «механистическое» применение.

Прямое действие решений ЕСПЧ 8 наииональном праве. По утвержАениям некоторых авторов, постановмения Европейского суда имеют прямое действие в рамках национального правопорядка. Например, А.Т. Караманукян отмечает, что «в ряде государств - участников Конвенции решения Европейского суда реализуются сразу же после их принятия, что фактически означает прямое действие решений Суда во внутреннем праве... Аопушенные нарушения исправцяются... непосредственно Аействиями внутренних правоприменительных органов» [13, с. 74]. При этом утверждается, что «в тех странах, где такое прямое действие решений Суда имеет место, публикаџия судебного решения в юридических изданиях иногда может быть Аостаточной для его исполнения, так как суды автоматически принимают во внимание опубликованные решение и, соответственно, предотвращают подобные нарушения в своей практике» $[13,14$, c. 29] .

Вряд ми можно согласиться с тем, что решения Европейского суда могут исполняться на основании самой их публикации и, конечно, с тем, что суды «автоматически» исполняют решения ЕСПЧ. На наш взгляА, тезис о прямом действии постановлений ЕСПЧ, во-первых, может распространяться не на само решение в его резолютивной части, а мишь на высказанные Судом правовые позиции. По сути, решение ЕСПЧ в конкретном скучае представмяет собой акт применения права и в этом смысле подмежит исполнению национальными органами государственной власти. Вместе с тем мюбое решение Европейского суда по конкретному делу представмяет собой акт толкования Конвенции, которое может весьма существенно от-

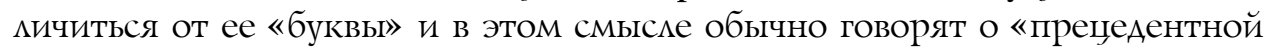
практике» ЕСПЧ. .

Некоторые ученые, механически распространяя догматические конструкции отечественной теории права на деятельность Европейского суда, полагают, что подобное эволютивное, или «квазиправотворческое», толкование положений ЕКПЧ является «самовольным» расширением компетенции Суда, выходом за пределы своих полномочий. Например, профессор В.В. Ершов пишет: «...” конвенџиальная техника толкования” в 


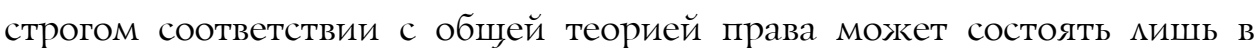
буквальном уяснении Европейским судом по правам человека точного смысла Конвенции и соответствуюшем ее разъяснении» [15, с. 486]. ОАнако Европейский суА, очевиАно, не желает соотносить свое толкование Конвенции с «общей теорией права» и выработанные им в результате такого толкования прецеденты, безусловно, преАставмяют собой источник права, обязательный для государств - участников Конвенџии. Аругое Аело, что данный источник, в отличие от самой Конвенции, которая непосредственно имплементируется в наџиональную правовую систему, носит факультативный характер: здесь правильнее говорить именно о «действии», а не «применении» прецедентной практики Европейского суда. Речь идет об учете правовых позиџий ЕСПЧ национальными судами (как правило, конституционными или судами высшей инстанции) при принятии собственных решений, опирающихся на национальное законодательство. Определенным исключением является ситуация в Украине, где принят Закон «Об исполнении решений и применении практики Европейского суда по правам человека». Согласно ст. 17 данного Закона суды применяют при рассмотрении дем Конвенџию и практику Суда как источник права.

Представцяется сомнительным, что на основании этого Закона национальные суды начнут непосредственно применять практику Европейского суда: Украина, как и Россия, явцяется страной континентальной системы права, где правовой прецедент не явмяется источником права «де юре». Прецедент является источником права в странах англосаксонского права, где действует правило «stare decisis» (буквально - стоять на решенном). Но, на взгляд исследователей Аанной проблематики, и в странах прецедентного права приоритет отдается не практике ЕСПЧ, а национальным прецедентам. В связи с имевшимися прецедентами украинский юрист Ю. Попов высказал мнение, что положение ст. 17 Закона Украины «О выполнении решений и применении практики Европейского суда по правам человека» «не создает регулирования, а потому не является нормой, а является теоретическим выводом... которому место не в законе, а в учебнике» [16, с. 51].

Взамен Ю. Попов предмагает рассматривать практику толкования Конвенции Европейским судом как «убедительные прецеденты» (persuasive precedent), которые сами по себе не образуют обшеобязательных правиц в качестве самостоятельных источников права, но «тем не менее, учитывая авторитетность суда, который их принял, существенно вАияют на практику Аругих судов, хотя и не явцяются обязательными Аця них». В этом смысле можно утверждать, что «действие» правовых позиций Европейского суда должно пониматься не как их «применение», а скорее, как «учет» мнения межкгосударственного органа. Именно такой подход выражен и в постановлении Пиенума Верховного Суда РФ от 27 июня 2013 г. № 21 
«О применении судами общей юрисдикщии Конвенщии о защите прав человека и основных свобод от 4 ноября 1950 года и Протоколов к ней». В частности, в данном документе отмечается, что с целью эффективной защиты прав и свобод человека российскими судами должны учитываться правовые позиџии Европейского суда, принятые в отношении других государств - участников Конвенции.

В отношении прецедентных решений, вынесенных против Российской Федерации, Пиенум констатировац обязательность дия наџиональных суАов правовых позиций Европейского суда по правам человека. При этом особо отмечается, что содержание прав и свобод, предусмотренных законодательством Российской Федерации, должно определяться с учетом содержания аналогичных прав и свобод, раскрываемого Европейским судом при применении Конвенщии и протоколов к ней.

Весьма мюбопытный способ исполнения решений Европейского суда в части принятия мер общего характера сформировался в Италии, где существует особый вид источников права - декрет-законы. Как известно, понятие «декрет» в юриспруденции служит Аля обозначения нормативноправового акта, который может быть равносилен закону, принимаемому не парламентом, а органом исполнительной власти или главой государства. Согласно ст. 77 Конституции Италии Правительство Республики в случаях особой необходимости и срочности под свою ответственность принимает временные распоряжения, имеющие силу закона - декреты. ОАнако в этом случае оно должно в тот же день преАставить их Аля утверждения в парламент, который в течение шестидесяти дней после опубликования может их утвердить, и кишь тогда декрет получает сицу закона. Аекрет, не утвержденный парламентом в течение данного срока, теряет юридическую силу. Именно поэтому данный виА нормативно-правовых актов в Аоктрине получиц наименование «декрет-закон».

Как отмечается в специальной митературе, «декреты-законы» «принимаются правительством поА свою ответственность в случаях особой необходимости и срочности. Например, правительство принимает декреты-законы при возникновения чрезвычайных обстоятельств, требующих незамедлительного законодательного вмешательства» [17, с. 43]. Аекреты-законы используются итальянским правительством также дия принятия мер обшего характера, необходимых Аля исполнения решений Европейского суда по правам чемовека [18] .

«Механизм неисполнения» решений ЕСПЧ, или... Как справедяиво отмечает А.С. Исполинов, по большей части «решения ЕСПЧ носят декла-

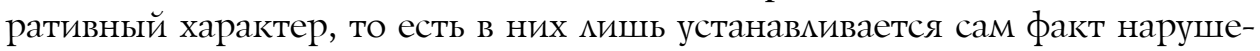
ния государством своих обязательств по Конвенции, но не преАписывается никаких конкретных мер, кроме выплаты (и то не всегда) относительно скромной компенсации заявителю» [19, с. 57]. Как правило, Европейский суА исходит из принџипа широкого усмотрения государств-участ-

22 Bulletin of the Volga Region Institute of Administration • 2020. Vol. 20. № 6 
ников относительно конкретных способов и средств устранения такого нарушения Конвенции. Отсутствие возможкности контролировать национальные демократические процедуры принятия политических решений (которое стало очевидным еще после дела Херста) вынуждает Европейский суА принимать на себя роль свекрови из известного анекдота - «не знаю как, но не так».

Собственно, это и приводит к выводу, который озвучия суА г. Наумбурга: Конвенция обязывает государство, но не демократические институты власти, такие как суд ици парламент, обладающие Аостаточной степенью автономии и независимости при принятии решений. Аргумент Федерацьного конституционного суда Германии относительно того, что в силу межАународных обязательств страны все ее государственные органы обязаны учитывать как положения Конвенции, так и практику ЕСПЧ, принципиально ничего не меняет в этом выводе.

Но если этот факт принимают и Европейский суд по правам человека, и государства - участники Конвенции, то остается непонятным, Аця чего России понадобился механизм «проверки конституционности» решений ЕСПЧ Конституџионным Судом РФ. В первую очередь необходимо отдавать себе отчет, что Аанный правовой институт по сути явцяется правовым механизмом неисполнения решений ЕСПЧ. Именно с этой целью он был введен в российское законодательство и с этой же целью однажАы уже бым использован на практике: имеется в виду не дело Анчугова и Гладкова, где проблема закцючалась в существовании действительного, а не мнимого или наАуманного противоречия положениям российской Конститущии, а Аело «ЮКОСа», гАе такого противоречия не было.

Известный специалист в области конституционного права профессор кафедры пубцичного права, сравнительного правоведения и российского права Университета им. Гумбольта (Берлин) А. Бланкенагель совершенно справедливо отмечает: «Предполагаемое «неверное» постановление ЕСПЧ не выходит за рамки ст. 79 российской Конституции: оно не нарушает суверенитета Российской Федерации, не вводит (прямых) ограничений основных прав и свобод российских граждан - обязанность возмещать ущерб является обязанностью Российского государства и не противоречит основам конституционного строя, закрепленным в главе 1 Конституции. Совсем наоборот: оно никоим образом не преАставцяет собой - в отличие от дела Анчугова и Гладкова - эволюционное толкование, которое, как мы помним, явцяется основанием Аця постановки проблемы неисполнения решений ЕСПЧ» [20, с. 58]. Аругое Аело, что Европейский суА, безусловно, «перегнул палку» в части определения размера такой компенсации, «придав ей штрафной характер, сформированный из непрозрачности и непредсказуемости расчетов» [21, с. 218]. ОАнако, что касается исполнения этого решения Европейского суда, следует согласиться, что Россия изначацьно не собирацась 
выплачивать столь огромную сумму. И в данном случае упомянутый механизм конституџионного обоснования неисполнения решений ЕСПЧ оказался как нельзя кстати уместным.

В постановцении от 14 июця 2015 г. № 21-П, где Конституционный Суд РФ наиболее решительно высказался относительно «пределов своей уступчивости», и которое, собственно, открыло законодателю дорогу к созданию упомянутого правового механизма, приводился ряА примеров отстаивания интересов наџиональной конституции из зарубежннй конституционной практики. В частности, помимо уже названных дел Херста и Гергюлю, Суа выделил решение Конституџионного Суда Итальянской Республики относительно постановления ЕСПЧ по делу «Маджо (Maggio) и другие против Италии». ОАнако, как справеАливо указывают в специальной митературе, несмотря на «громкие заявления» национальных конституционных инстанџий, ни в одной из этих стран не был предусмотрен «регулярный» механизм отказа от исполнения решений Европейского суда - «большинство государств предпочитает молчаливо игнорировать решения ЕСПЧ» [22, с. 467].

В свою очередь, нормативное закрепление подобной возможности вызвало настояший «ажиотаж» со стороны Европейского суда: в частности, в заключении, принятом Венецианской комиссией был сАелан вывоА, что полномочие КС РФ принимать решения о «невозможности исполнения» постановмений ЕСПЧ несовместимо с межАународно-правовыми обязательствами России [23]. Аналогичное заключение было принято Венецианской комиссией и в отношении поправки в конституџию, закрепляющую данный механизм уже в Основном Законе РФ [24] .

По словам А. Бланкенагемя, «проблема заключается в опасении того, что Россия и КС РФ, независимость которого подвергается сомнению в кулуарных разговорах, будут змоупотребцять своими новыми полномочиями». Всем понятно, что судебные решения иногда не исполняются, и пока такое неисполнение не достигает “критической массы”, оно не влечет серьезных последствий для авторитета суда. Так, можкет быть, имеет смысл просто тихо принять некоторые случаи неисполнения решения ЕСПЧ, если большинство решений соблюдается?» [20, с. 59] .

На наш взгляА, подобный вывод Аемается из принятия «худшего варианта» развития событий, который, заметим справедливости ради, в настоящей политической ситуации не только не исключается, но и явцяется наиболее вероятным. ОАнако стоит задуматься и о том, что с учетом широкой дискреџии государства в области конкретных способов исполнения решения ЕСПЧ, с оАной стороны, и весьма ограниченной возможности использовать для этого предусмотренные национальным законодательством демократические проџедуры, с Аругой, выбор мер «общего характера» преАставляется весьма нетривиальной проџедурой. И в Аанной ситуации мнение Конституционного Суда РФ о возможности исполнения

24 Bulletin of the Volga Region Institute of Administration • 2020. Vol. 20. № 6 
решения Европейского суда, то есть о конкретных мерах и способах его исполнения, было бы весьма нелишним. Вместо использования интемлектуального ресурса судей Конституџионного Суда РФ Амя того, чтобы обосновать, почему Россия не собирается исполнять то или иное решение ЕСПЧ, можно направить эти усилия на решение вопроса, как можно разрешить проблему и исполнить это решение пусть не буквально, но в возможно приемлемой форме.

В итоге Комитет министров Совета Европы (CЕ) с учетом всех обстоятельств пришел к выводу, что Россия исполника решение Европейского суда по правам человека (ЕСПЧ) по делу «Анчугов и Гцадков против России» [25]. Такое решение было принято с учетом того, что значительная часть осужденных за преступления небольшой или средней тяжести приговариваются к наказанию в виде общественных работ (их Комитет министров СЕ рассматривает как анамог мишения свободы) и при этом они не лишаются активного избирательного права. Но ведь именно подобный вариант решения проблемы обозначия Конституционный Суа РФ в своем постановлении от 19 апремя 2016 г. № 12-П: «...законодатель правомочен, последовательно реализуя принцип гуманизма в угомовном праве, оптимизировать систему уголовных наказаний, в том числе посредством перевода отдельных режимов отбывания мишения свободы в альтернативные виды наказаний, хотя и связанные с принудительным ограничением свободы осужденных, но не влекущие ограничения их избирательных прав».

Этой «благостной картине» сегодня мешает слабая и зависимая роль Конституционного Суда РФ в системе разделения властей, в рамках которой Суа оказывается весьма уязвим Аля агрессивной политики исполнительной власти. Судите сами: сначала «путешествие из Москвы в Петербург», потом - назначение Председателя вместо его избрания судьями, затем - пожизненное замещение должности Председателя КС РФ. И вот в ходе конституционной реформы было намечено сокращение числа судей КС РФ с девятнадџати до одиннадџати (а фактически АО восьми, что Аопускает кворум).

В заключение отметим, что ситуация, которая скмадывается в связи с исполнением, точнее, неисполнением решений Европейского суда по правам человека, обусловлена объективной проблемой «столкновения», если не Авух правопорядков, то Авух юрисдикций. В такой ситуации проблема юридической неопределенности неизбежна, однако напомним, что граждане России обладают не только правом на обращение за защитой своих прав в межгосударственные органы, но и правом на эффективную судебную защиту. Как справедливо отмечается, «понятие "судебная защита" преАполагает признание и исполнение принятых решений ЕСПЧ, хотя бы в части признания факта нарушения прав и свобод и выплаты денежной компенсации, но никак не игнорирование их» [21; 22, с. 471]. 
Выдающийся русский ученый-юрист И.А. Покровский писал: «...ичность желает иметь свое опредеменное и прочное место, желает жить на своем праве, а не на милости или немилости государства. Но этого мало: в известных областях она идет еще далее и заявцяет претензию на полную независимость от государственной регламентаџии: если юридическое поможение человека вообще может быть изменено новым законом, то есть такие “неотъемлемые права человека", которые никаким законом уничтожены быть не могут, которые даже Аля государства в целом недосягаемы. Если всякое субъективное право обеспечивает цичность от произвола властей, то идея “неотъемлемых прав" направмяется против государства как такового» [26, с. 309].

Юстициабельность этих «неотьемлемых прав» весьма специфична: она может быть обеспечена только посредством деятельности национальных конституционных судов и межгосударственных органов по защите прав человека. Именно они, включая Европейский суд по правам человека, незаменимы в тех исключительных случаях, когда необходимо привлечь к ответственности государство, в чем и заключается наиболее полная реализация конџепџии верховенства права и правовой определенности Аичности.

\section{Библиографический список}

1. Дело «Анчугов и Гладков (Anchugov and Gladkov) против Российской Федерации»: постановление ЕСПЧ от 4 июля 2013 г. // Бюллетень Европейского суда по правам человека (российское издание). 2014. № 2.

2. Пресняков М.B. Прямое действие Конституции Российской Федерации и ее отраслевая интерпретация // Гражданин и право. 2014. № 11. С. 3-14.

3. Дело «Константин Маркин (Konstantin Markin) против России» (жалоба № 30078/06) [англ.]: постановление ЕСПЧ от 7 окт. 2010 г. URL: http://www.echr.coe.int.

4. Постановление Европейского суда по делу «Херст (Hirst) против Соединенного Королевства (№ 2)» от 6 окт. 2005 г. (жалоба № 74025/01) [Электронный ресурс]. Доступ из СПС «КонсультантПлюс».

5. Дело «Фродль против Австрии» [Frodl v. Austria] (жалоба № 20201/04): постановление Европейского суда по правам человека от 8 апр. 2010 г. [Электронный ресурс]. Доступ из СПС «КонсультантПлюс».

6. Дело «Скоппола (Scoppola) против Италии (№ 2)» (жалоба № 10249/03) [рус., англ.]: постановление ЕСПЧ от 17 сент. 2009 г. [Электронный ресурс]. Доступ из СПС «КонсультантПлюс».

7. Ковлер А.И. Избирательное право и его избирательное толкование (к вопросу о судейском активизме) // Права человека. Практика Европейского суда по правам человека. 2013. № 10. C. 7-16.

8. О применении судами общей юрисдикции общепризнанных принципов и норм международного права и международных договоров Российской Федерации: постановление Пленума Верховного Суда РФ от 10 окт. 2003 г. № 5 // Бюллетень Верховного Суда РФ. 2003. № 12. 
9. Case of Gurgblь v. Germany, No. 74969/01, judgment of 26 February 2004. URL: https:// www.rewi.hu-berlin.de/de/lf/oe/hfr/deutsch/2006-12.pdf

10. Герасимова Е.В., Ширинян С.В. Постановления Европейского суда по правам человека в правовой системе Федеративной Республики Германия // Вестник Балтийского федерального университета имени И. Канта. Сер.: Гуманитарные и общественные науки. 2017. № 2. C. 5-13.

11. URL: https://zakon.ru/blog/2013/11/18/delo_gyorgyulyu_germaniya_vybiraet_mir_s_ espch\#comment_81787

12. Постановление Федерального конституционного суда Германии от 10 июня 2005 г. № 1BvR 2790/04 по жалобе К. Гёргюлю. URL: http://www.bundesverfassungsgericht.de/ SharedDocs/Entscheidungen/DE/2005/06/rk20050610_1bvr 279004.html

13. Караманукян Д.Т. Акты Европейского суда по правам человека в российской правовой системе: учебное пособие. Омск, 2013.

14. Осман-заде C. Европейская конвенция по правам человека и национальные правовые системы стран - членов Совета Европы. Роль Комитета министров // Юрист-международник. 2005. № 2. С. 21-30.

15. Ершов В.В. Правовое и индивидуальное регулирование общественных отношений. М., 2018.

16. Попов Ю. Решения Европейского суда по правам человека как необязательные убедительные прецеденты: английский и украинский опыт // Предпринимательство, государство и право. 2010. № 11. С. 49-52.

17. Малиновская B.M. Понятие и источники административного права Италии // Право и управление. XXI век. 2015. № 4 (37). С. 39-45.

18. Полличино $O$. Совершенствование национальных механизмов эффективной реализации Европейской конвенции по правам человека - доклад по Италии // Совершенствование национальных механизмов эффективной имплементации Европейской конвенции по правам человека, Санкт-Петербург, 22-23 окт. 2015 г. URL: https://rm.coe. int/16806flda1. C. 55-64.

19. Исполинов А.С. Исполнение решений международных судов: теория и практика // Международное правосудие. 2017. № 1. С. 45-67.

20. Бланкенагель $A$. Европейский суд по правам человека против российского Конституционного Суда: о нормальных трениях, скрытых угрозах и предвзятой близорукости // Закон. 2019. № 6. С. 52-60.

21. Сидоренко М.A. О присуждении справедливой компенсации (из практики Европейского суда по правам человека) // Власть Закона. 2018. № 2. С. 210-225.

22. Худолей K.M. Отказ от исполнения решений международных судебных органов по защите прав и свобод граждан // Вестник Пермского университета. Юридические науки. 2017. Вып. 38. С. 463-473.

23. URL: https://wcd.coe.int/ViewDoc.jsp?Ref=DC-PR042(2016)\&Language=lanRussian $\&$ Ver $=$ original $\&$ Site $=$ DC $\&$ BackColorInternet $=$ F5CA75\&BackColorIntranet $=$ F5CA75 $\&$ Back ColorLogged=A9BACE

24. URL: https://www.venice.coe.int/webforms/documents/?pdf=CDL-AD(2020)009e\&fbclid=IwAR1JO8IojBv-7uxOyz9s 14a-WK6mMVaGYrPTR1oHN-PGPp24WqO4UCusTRw

25. URL: https://search.coe.int/cm/Pages/result_details.aspx?ObjectID=0900001680972e12.

26. Покровский И.А. Основные проблемы гражданского права. М., 1998. 